\title{
Trifolium repens-Associated Bacteria as a Potential Tool to Facilitate Phytostabilization of Zinc and Lead Polluted Waste Heaps
}

\author{
Ewa Oleńska ${ }^{1, *(D)}$, Valeria Imperato ${ }^{2}$, Wanda Małek ${ }^{3}$, Tadeusz Włostowski ${ }^{4}$, \\ Małgorzata Wójcik $^{5}$, Izabela Swiecicka ${ }^{1,6}$, Jaco Vangronsveld ${ }^{2,5}$ (D) and Sofie Thijs ${ }^{2, *(1)}$ \\ 1 Department of Microbiology and Biotechnology, Faculty of Biology, University of Białystok, \\ Ciołkowskiego 1J, 15-245 Białystok, Poland; izabelas@uwb.edu.pl \\ 2 Faculty of Sciences, Centre for Environmental Sciences, Hasselt University, Agoralaan D, \\ B-3590 Diepenbeek, Belgium; valeria.imperato@uhasselt.be (V.I.); jaco.vangronsveld@uhasselt.be (J.V.) \\ 3 Department of Genetics and Microbiology, Institute of Biological Sciences, Faculty of Biology \\ and Biotechnology, Maria Curie-Skłodowska University, Akademicka 19, 20-033 Lublin, Poland; \\ wanda.malek@poczta.umcs.lublin.pl \\ 4 Department of Evolutional and Physiological Ecology, Faculty of Biology, University of Białystok, \\ Ciołkowskiego 1J, 15-245 Białystok, Poland; twlostow@uwb.edu.pl \\ 5 Department of Plant Physiology and Biophysics, Institute of Biological Sciences, Faculty of Biology \\ and Biotechnology, Maria Curie-Skłodowska University, Akademicka 19, 20-033 Lublin, Poland; \\ m.wojcik@poczta.umcs.lublin.pl \\ 6 Laboratory of Applied Microbiology, Faculty of Biology, University of Białystok, Ciołkowskiego 1J, \\ 15-245 Białystok, Poland \\ * Correspondence: chwelat@uwb.edu.pl (E.O.); sofie.thijs@uhasselt.be (S.T.); Tel.: +48-85-738-83-66 (E.O.); \\ $+32-11-26-82-25$ (S.T.)
}

Received: 1 July 2020; Accepted: 5 August 2020; Published: 6 August 2020

\begin{abstract}
Heavy metals in soil, as selective agents, can change the structure of plant-associated bacterial communities and their metabolic properties, leading to the selection of the most-adapted strains, which might be useful in phytoremediation. Trifolium repens, a heavy metal excluder, naturally occurs on metal mine waste heaps in southern Poland characterized by high total metal concentrations. The purpose of the present study was to assess the effects of toxic metals on the diversity and metabolic properties of the microbial communities in rhizospheric soil and vegetative tissues of T. repens growing on three 70-100-years old $\mathrm{Zn}-\mathrm{Pb}$ mine waste heaps in comparison to Trifolium-associated bacteria from a non-polluted reference site. In total, 113 cultivable strains were isolated and used for $16 \mathrm{~S}$ rRNA gene Sanger sequencing in order to determine their genetic affiliation and for in vitro testing of their plant growth promotion traits. Taxa richness and phenotypic diversity in communities of metalliferous origin were significantly lower $(p<0.0001)$ compared to those from the reference site. Two strains, Bacillus megaterium BolR EW3_A03 and Stenotrophomonas maltophilia BolN EW3_B03, isolated from a $\mathrm{Zn}-\mathrm{Pb}$ mine waste heap which tested positive for all examined plant growth promoting traits and which showed co-tolerance to $\mathrm{Zn}, \mathrm{Cu}, \mathrm{Cd}$, and $\mathrm{Pb}$ can be considered as potential facilitators of phytostabilization.
\end{abstract}

Keywords: Trifolium repens; bacterial endophytes; metals; plant growth promotion; phytoremediation; 16S rRNA gene

\section{Introduction}

As a result of extensive anthropogenic industrial and agricultural activities, numerous soils are polluted with metals at concentrations that are toxic to ecosystems and to human health [1,2]. Heavy 
metals, being inorganic compounds, do not undergo any process of biodegradation and therefore they persist in soils for decades or centuries, maintaining their potential toxicity. To reduce or even eliminate the risks of these hazardous elements in the environment different physicochemical remediation approaches (i.e., soil washing, adsorption, biosorption, precipitation, and chelation with alginates, citrates, flavonoids, and phytic acid) have been developed [3]. However, it turned out that these methods hold significant limitations leading to the disturbance of ecosystems, e.g., altering the biological and physicochemical properties of soil and/or negatively affecting indigenous soil microbial communities [4]. As an alternative to physicochemical remediation methods, a biological innovative, environmentally friendly, and cost-efficient tool, based on the usage of vascular plants to extract, sequester, and/or detoxify pollutants, generally termed as phytoremediation, has been developed [5-8].

Phytoremediation relies on various mechanisms which plants can use to deal with metal toxicity, avoiding the transfer of metals into the cells or activation of intracellular mechanisms, which provide the basis of the whole plant tolerance system against deleterious metals [9]. Plants express their tolerance to heavy metals using a strategy of (i) accumulation, i.e., extracting toxic elements from soil and accumulating them in the harvestable, above-ground plants parts; or (ii) exclusion, which relies on the ability to exclude metals from the shoots, and concentrate them on/in roots, thus reducing their further spreading due to wind or water erosion, percolation to the groundwater and the risk of additional environmental harm [5,10-12]. Such evolutionary acquired adaptations of plants to withstand metal toxicity can be exploited for phytoextraction or phytostabilization, respectively.

The efficiency of the restoration of metal polluted soils can be substantially enhanced by the simultaneous application of plants with microbes [13]. It has been shown that endophytes inhabiting plant tissues may significantly improve phytoremediation [6]. For each individual polluted site, the most effective plant-microbe associations must be selected. Microorganisms may exert positive effects on plants indirectly, detoxifying noxious ions using different tolerance mechanisms [14,15], and directly by influencing plant biomass production [16,17]. Plant growth promoting (PGP)-bacteria are defined as microbes able to act beneficially on plant growth by (i) synthesizing phytohormones (e.g., indolyl-3-acetic acid-IAA) or influencing their level (1-aminocyclopropane-1-carboxylic acid-ACC deaminase as an ethylene biosynthesis inhibitor); (ii) increasing the availability of nutrients, e.g., nitrogen $\left(\mathrm{N}_{2}\right.$ fixation), phosphorus (solubilization and mineralization of phosphorus forms), and iron (by synthesising siderophores); (iii) controlling pathogens and preventing plant infections by, e.g., direct antagonism against pathogens, competition for nutrients, and activation of induced systemic resistance (ISR) in plants $[5,18,19]$. Indeed, some endophytes of metallicolous plants can synthesize auxins and/or siderophores and are able to supply plants with nutrients of limited availability [20]. For instance, Sánchez-López et al. [21] reported the high prevalence of endophytes isolated from Crotolaria pumila growing on metal mine residues with capabilities to synthesize ACC deaminase, to produce siderophores, acetoin, IAA, to solubilize phosphorus, and to fix atmospheric nitrogen.

The 70-100-year old zinc-lead ( $\mathrm{Zn}-\mathrm{Pb})$ mine waste heaps, Bolesław, Bukowno and Saturn, localized in the Silesia-Kraków Upland (Poland), are post-industrial and post-mining deposits. These habitats are extremely heterogeneous, scarce in water and nutrients and with high mean total concentrations of metals up to 52,795 $\mu \mathrm{g} \mathrm{Zn,} 578 \mu \mathrm{g} \mathrm{Pb}$, and $605 \mu \mathrm{g}$ cadmium (Cd) per g dry soil (see Table 1). In spite of such unfavorable conditions, metal-rich waste heaps are inhabited by vegetation covers of uneven density. Legumes (Fabaceae) are one of the most common families present on these sites. Legumes include several pioneer species, able to colonize marginal soils and to improve the nutritional status and organic matter content (and thus water-holding capacity) of the soils they are growing on. Trifolium repens (white clover) is such a species that spontaneously colonizes most $\mathrm{Zn}-\mathrm{Pb}$ containing waste heaps in southern Poland [22,23]. 
Table 1. Concentrations of total $\mathrm{Zn}, \mathrm{Pb}$, and $\mathrm{Cd}\left(\mu \mathrm{g} \mathrm{g}^{-1}\right)$ in soils as well as in roots and leaves of white clover from the non-polluted reference area and the polluted sites in Bolesław, Bukowno, and Saturn.

\begin{tabular}{|c|c|c|c|c|c|c|c|c|c|}
\hline & \multicolumn{3}{|l|}{ Soil } & \multicolumn{3}{|l|}{ Root } & \multicolumn{3}{|l|}{ Leaf } \\
\hline & $\mathrm{Zn}$ & $\mathbf{P b}$ & $\mathrm{Cd}$ & $\mathrm{Zn}$ & $\mathrm{Pb}$ & $\mathrm{Cd}$ & $\mathrm{Zn}$ & $\mathrm{Pb}$ & $\mathrm{Cd}$ \\
\hline Bolesław & $52,795 \pm 1197^{\mathrm{a}}$ & $578 \pm 5^{\mathrm{a}}$ & $605 \pm 73^{a}$ & $609 \pm 41^{\mathrm{a}}$ & $243 \pm 80^{\mathrm{a}}$ & $288 \pm 161^{\text {a }}$ & $329 \pm 22^{a}$ & $7.10 \pm 1.12^{\mathrm{a}}$ & $1.80 \pm 0.16^{\mathrm{a}}$ \\
\hline Bukowno & $20,159 \pm 1523^{b}$ & $35 \pm 11^{b}$ & $18 \pm 2^{b}$ & $405 \pm 76^{b}$ & $2.85 \pm 0.11^{b}$ & $1.25 \pm 0.04^{b}$ & $190 \pm 11^{b}$ & $0.59 \pm 0.08^{\mathrm{b}}$ & $0.36 \pm 0.02 \mathrm{~b}$ \\
\hline Saturn & $26,016 \pm 2757^{b}$ & $48 \pm 11^{b}$ & $22 \pm 9^{b}$ & $499 \pm 89^{b}$ & $3.26 \pm 0.07^{b}$ & $5.89 \pm 0.18^{b}$ & $221 \pm 20^{b}$ & $0.62 \pm 0.1^{b}$ & $1.20 \pm 0.17^{c}$ \\
\hline Bolestraszyce & $64 \pm 25^{c}$ & $6.87 \pm 1.65^{c}$ & $2.56 \pm 0.74^{\mathrm{c}}$ & $2.7 \pm 0.39^{c}$ & $0.45 \pm 0.25^{c}$ & $0.51 \pm 0.05^{c}$ & $0.41 \pm 0.09^{c}$ & $0.01 \pm 0.005^{c}$ & $0.08 \pm 0.02^{\mathrm{d}}$ \\
\hline
\end{tabular}

Concentrations of $\mathrm{Zn}, \mathrm{Pb}$, and $\mathrm{Cd}$ are presented as mean $\pm \mathrm{SD}$ for $n=5$. Means in the same column marked with a different superscript letter are significantly different $(p<0.05)$ (ANOVA, Duncan's multiple range test).

Oleńska and Małek [23] have recently demonstrated that the high metal concentrations in the soils of these waste heaps act as a natural selection factor shaping the genetic structure of native bacterial populations. A reduction of the genomic polymorphism of Rhizobium leguminosarum bv. trifolii strains isolated from root nodules of T. repens growing on the old Bolesław $\mathrm{Zn}-\mathrm{Pb}$ waste heap in comparison with a reference $R$. leguminosarum bv. trifolii population from a non-polluted grassland, and genotypes adapted to high metal conditions were revealed [15,22]. It cannot be excluded that the extreme levels of toxic metals present in metal-rich waste heaps may influence the composition of bacterial communities, their properties, and associations with plants. Bidar et al. [24] showed the underground-tissue-accumulation of toxic metals in T. repens, which indicates that this species is a potential excluder and possible phytostabilizer. Therefore, knowledge about the taxonomical composition of the Trifolium associated microbiome, particularly about the rhizospheric bacterial communities and their possible beneficial traits for the host-plant, is of great importance in a context of the use of white clover as a potential species for phytostabilization. It was reported that nodules of leguminous plants are not exclusively inhabited by rhizobia, and that they might coexist with other microbial communities including mycorrhizal fungi $[25,26]$. Furthermore, Sanchez-Lopez et al. [21] showed that the microbiome of vegetative plant tissues may influence the fitness of its host-plant growing on a metal polluted soil. Since there exists a huge shortage of knowledge about the microbiome of the potential phytostabilizer T. repens, and its probable evolutionary adaptation to long-term metal exposure, the purpose of the present study was to determine the effect of metals on the diversity and phenotypic properties of the cultivable bacterial communities inhabiting soil, nodules, roots, and leaves of T. repens growing on three 70-100-year old $\mathrm{Zn}-\mathrm{Pb}$ waste heaps (Bolesław, Bukowno, and Saturn) in comparison to T. repens originating from a reference non-polluted grassland in Bolestraszyce. In order to elucidate the taxonomic position of 113 bacterial cultivable isolates obtained from calaminarian and non-polluted grasslands, 16S rRNA gene analysis was applied. Moreover, to obtain wider knowledge about potential bacterial involvement in phytoremediation, several plant growth promotion traits (synthesis of auxins, siderophores, organic acids, acetoin, ACC-deaminase activity, phosphorus solubilization, and nitrogen fixation abilities) of the studied strains as well as their metal $(\mathrm{Zn}, \mathrm{Cd}, \mathrm{Cu}$, and $\mathrm{Pb})$ tolerance, were investigated.

\section{Materials and Methods}

Bacteria were isolated from leaves, roots, nodules, and rhizosphere of white clover (Trifolium repens L.) growing on three (70-100 year-old) metalliferous waste heaps in Bolesław $\left(50^{\circ} 17^{\prime} \mathrm{N}\right.$ $\left.19^{\circ} 29^{\prime} \mathrm{E}\right)$, Bukowno $\left(50^{\circ} 16^{\prime} \mathrm{N} 19^{\circ} 28^{\prime} \mathrm{E}\right)$, and Saturn $\left(50^{\circ} 17^{\prime} \mathrm{N} 19^{\circ} 4^{\prime} \mathrm{E}\right)$ situated in the Silesia-Kraków Upland (South Poland), and a non-polluted reference grassland area in Bolestraszyce $\left(49^{\circ} 48^{\prime} \mathrm{N} 22^{\circ} 50^{\prime} \mathrm{E}\right)$ (Przemyskie Foothills, Southeastern Poland) in June 2017. Plant and soil samples were collected randomly from each site. Samples were taken aseptically from the upper $10 \mathrm{~cm}$ soil layer, using a sterilized shovel and stored in sterile plastic bags. Closed bags were kept in a temperature controlled cool box $\left(4-8^{\circ} \mathrm{C}\right)$, and transferred immediately to the laboratory. 


\subsection{Isolation of Plant-Associated Bacteria}

\subsubsection{Isolation of Endophytes}

Leaves, roots, and nodules of T. repens were subjected to a surface sterilization. After washing them in tap water, the tissue samples were immersed in a $0.1 \%$ sodium hypochlorite solution $(6 \%-14 \%$ active chlorine EMPLURA ${ }^{\circledR}$ EMD Millipore) for $10 \mathrm{~s}$, and rinsed three times in sterile deionized water. The sterilization effectiveness was verified by plating $100 \mu \mathrm{L}$ of the last rinsing water on a solid rich 869 medium, which is an appropriate medium for the detection of the diversity of plant endophytes [27]. Approximately $250 \mathrm{mg}$ of plant tissue was homogenized in sterile $10 \mathrm{mM} \mathrm{MgSO}_{4}$, and subsequently $100 \mu \mathrm{L}$ of the plant extract dilution to obtain a $10^{-4}$ concentration was plated on a solid 1/10 869 medium [27]. After four days of incubation at $30^{\circ} \mathrm{C}$, the single bacterial colonies showing different morphologies were plated separately on 1/10 869 plates. The pure cultures of isolated bacteria were suspended in sterile deionized water containing glycerol $(15 \% \mathrm{w} / \mathrm{v})$ and sodium chloride $(0.85 \% \mathrm{w} / \mathrm{v})$, and were stored in a freezer at $-45^{\circ} \mathrm{C}$.

\subsubsection{Isolation of Rhizosphere Bacteria}

In order to enlarge the access to the diverse soil microorganisms, a sandwich diffusion system was applied [28]. In brief, roots with tightly-adhering soil attached (rhizosphere) were suspended in $5 \mathrm{~mL}$ of $0.1 \mathrm{M}$ phosphate-buffered saline (PBS, $\mathrm{pH}=7.0)$ and incubated on an orbital shaker $(160$ $\mathrm{rpm}$ ). Rhizosphere soil suspensions diluted to $10^{-5}$ were added to the cooled R2A medium (in w/v\%, casein acid hydrolysate 0.05 , yeast extract 0.05 , protease peptone 0.05 , dextrose 0.05 , soluble starch $0.05, \mathrm{~K}_{2} \mathrm{HPO}_{4}$ 0.03, $\mathrm{MgSO}_{4} \times 7 \mathrm{H}_{2} \mathrm{O} 0.003$, sodium pyruvate 0.03, agar 1.5, pH 7.2) [29], supplied with $0.7 \% \mathrm{w} / \mathrm{v}$ Gelzan (Sigma-Aldrich, St. Louis, MO, USA) and $0.1 \% \mathrm{CaCl}_{2} \times 2 \mathrm{H}_{2} \mathrm{O}$. Into such mixture a perforated plate was dipped. After solidification of agar in the plate's holes, 47-mm diameter Nucleopore ${ }^{\circledR}$ polycarbonate track-etched membranes, of a 0.05- $\mu$ m pore size (Whatman, Maidstone, UK), which allow water and nutrients migration but prevent the efflux of bacteria out of the system, were placed on both sides of each perforated plate. Closed sandwich systems were buried into each soil, consistently watered with MilliQ, and incubated for three months at $20{ }^{\circ} \mathrm{C}$. After incubation, the sandwich diffusion systems were opened under laminar flow, membranes were removed, and each plug from the agar-filled perforate plate was pushed into an opposite well in a sterile Masterblock ${ }^{\circledR}$ (Greiner bio-one) filled with liquid R2A medium. Bacteria were incubated on an orbital shaker (160 $\mathrm{rpm}$ ) at $30^{\circ} \mathrm{C}$ for 4 days. Subsequently, $100 \mu \mathrm{L}$ of resuspension was plated onto solid R2A medium, single colonies were purified, transferred to a glycerol solution $(15 \% \mathrm{w} / \mathrm{v})$ and stored at $-45^{\circ} \mathrm{C}$.

\subsection{Genetic Analysis}

\subsubsection{Determination of Taxonomic Position of Bacteria Based on $16 \mathrm{~S}$ rRNA Gene Sequence}

The genomic DNA from each of the 113 isolated bacteria was extracted using the Applied Biosystems MagMAX ${ }^{\mathrm{TM}}$ Total DNA Multi-Sample Ultra Kit according the manufacturer's instructions (ThermoFisher Scientific). The DNA extraction was preceded by treatment of bacteria with a lysis buffer (lysozyme $90 \mathrm{mg}$, Tween20 $54 \mathrm{mg}$, TE-buffer $90 \mu \mathrm{L}$, and nuclease free water $4410 \mu \mathrm{L}$ ). The DNA concentration was determined by using Nanodrop 2.0 and agarose gel electrophoresis (1\% agarose in $1 \times$ TBE buffer). Amplification of a $16 \mathrm{~S}$ rRNA gene fragment was performed using $0.2 \mu \mathrm{L} 5 \mathrm{U} / \mu \mathrm{L}$ Fast Start High Fidelity Enzyme Blend, cooperating with specific reagents of the FastStart ${ }^{\mathrm{TM}} \mathrm{HF}$ (High Fidelity) PCR System (Sigma-Aldrich): $2.55 \mu \mathrm{L} 10 \times$ concentrated with $18 \mathrm{mM} \mathrm{MgCl}_{2}$ FastStart HF Reactive Buffer, $0.5 \mu \mathrm{L} 10 \mathrm{mM}$ PCR grade dNTP (deoxynucleoside triphosphate) mix, and 0.5 $\mu \mathrm{L} 0.2 \mu \mathrm{M}$ of each primer, diluted in $19.75 \mu \mathrm{L}$ nuclease free water. For amplification of 16S rDNA the following set of primers [30] were used: 27F 5'-AGAGTTTGATCMTGGCTCAG-3', and 1492R 5'-TACGGYTACCTTGTTACGACTT-3' (Macrogen, Netherlands) in following conditions: initial denaturation at $94{ }^{\circ} \mathrm{C}$ for $5 \mathrm{~min}, 35$ cycles of denaturation at $94{ }^{\circ} \mathrm{C}$ for $1 \mathrm{~min}$, annealing at $52{ }^{\circ} \mathrm{C}$ for 30 
sec, and extension at $72{ }^{\circ} \mathrm{C}$ for $3 \mathrm{~min}$, and final extension at $72{ }^{\circ} \mathrm{C}$ for $10 \mathrm{~min}$. The presence of PCR products was verified in a $1 \%$ agarose gel in $1 \times \mathrm{TBE}$ buffer, and documented with the Gel Doc System (Invitrogen). The Sanger sequence PCR was performed by Macrogen. The 16S rRNA gene sequences obtained in the present study were quality filtered and trimmed in Geneious v4.8.5. [31]. The high quality sequences were BLAST (Basic Local Alignment Search Tool) searched for the closest relative in the NCBI (National Center for Biotechnology Information) database.

\subsubsection{Phylogenetic and Genotypic Analysis}

Sequences of the 16S rRNA genes of the studied bacteria were analyzed with the Maximum Likelihood model using the MEGA 6.0 [32]. To compute the degree of the statistical support for branches in the phylogenetic tree, 1,000 bootstrap replicates were made. For an estimation of the relationships between individual strains of species, represented as nodes, minimum spanning trees (MSTs) were calculated; they consist of nodes connected by edges, the length of which corresponds to the distances between two individuals [33]. MSTs were calculated on the basis of nucleotide diversity according to the maximum parsimony method with the usage of the Arlequin ver. 3.5.2.2 software package [34].

\subsubsection{Determination of Relative Taxonomic Biodiversity in Communities}

In order to determine the relative taxonomic biodiversity of studied microbial communities originating from the three metal polluted sites and the non-polluted reference site, the Shannon's diversity index $\left(H^{\prime}\right)$ was used $[23,35,36]$. For the evaluation of the significance of the differences in taxonomical richness between studied microbial communities, their Shannon's diversity index $\left(H^{\prime}\right)$ values were subjected to the non-parametric U Mann-Whitney statistical test at the significance level $p<0.05$ with the usage of Statistica 13 software.

\subsection{Phenotypic Traits of Isolated Bacterial Strains}

\subsubsection{In vitro Studies Testing the Plant Growth Promoting Properties}

All isolated bacterial strains were tested for their ability to (i) enhance the levels of available nutrients, i.e., phosphate solubilization, nitrogen fixation, synthesis of organic acids, and siderophores; (ii) produce plant growth regulators, i.e., IAA synthesis, and ACC deaminase activity; and (iii) prevent plants diseases, i.e., acetoin synthesis. Most of the tests were performed using colorimetric assays, and some of them were achieved by plating on selective media. The bacterial capacity to solubilize phosphorus was verified according to Pikovskaya [37] with the modifications of Nautiyal [38]. The bacterial availability to fix atmospheric nitrogen was examined according to Xie et al. [39]. The ability to synthesize organic acids was done using Alizarine Red S according to Cunnigham and Kuiack [40]. Siderophores production was tested using chrome-azurol S according to Schwyn and Neilands [41], and 284 medium [42]. The capability of bacteria to synthesize IAA was explored according to the methods described by Gordon and Weber [43] and Patten and Glick [44]. Bacterial ACC-deaminase activity was studied according to Belimov et al. [45]. Bacterial acetoin production was examined using the $\alpha$-naphthol method [46].

\subsubsection{Metal Tolerance of Isolated Bacterial Strains}

Zinc, cadmium, copper, and lead tolerance of the strains were verified using liquid 284 medium [42] supplemented with different concentrations of metal salts: $0.4 \mathrm{mM}$ and $0.8 \mathrm{mM} \mathrm{CdCl}_{2} \times 2.5 \mathrm{H}_{2} \mathrm{O}, 0.6$ $\mathrm{mM}$ and $1.0 \mathrm{mM} \mathrm{ZnSO}_{4} \times 7 \mathrm{H}_{2} \mathrm{O}, 0.4 \mathrm{mM}$ and $0.6 \mathrm{mM} \mathrm{CuSO}_{4} \times 5 \mathrm{H}_{2} \mathrm{O}, 0.4$ and $1.0 \mathrm{mM} \mathrm{Pb}\left(\mathrm{NO}_{3}\right)_{2}$. Sterile microtitration cell culture plates (NEST Scientific), filled with $100 \mu \mathrm{L}$ mixture of 284 medium supplemented with the appriopriate dose of metals, were inoculated with the investigated strains. After five days of incubation on a shaker $(100 \mathrm{rpm})$ at $30^{\circ} \mathrm{C}$, the growth of all strains on metal supplemented media was evaluated as the absorbance measured at $\lambda=560 \mathrm{~nm}$ using a plate reader. 


\subsection{Analysis of Zinc, Lead, and Cadmium Concentration in Soils and T. repens Roots and Leaves}

Heavy metal content in the Bolesław, Bukowno, and Saturn upper layer of metalliferous and reference soil as well as in plant tissues were measured in five sample replicates. To determine total $\mathrm{Zn}, \mathrm{Pb}$, and $\mathrm{Cd}$ concentrations in soil samples, $0.2 \mathrm{~g}$ of soil matrix, previously passed through a $1 \mathrm{~mm}$ sieve, was extracted for $15 \mathrm{~min}$ with $70 \%$ nitric acid $(4.5 \mathrm{~mL})$ and hydrofluoric acid $(1.5 \mathrm{~mL})$ at $180{ }^{\circ} \mathrm{C}$ (Method 3052, US EPA 1996) in a Mars 6 microwave oven (CEM Corporation, Matthews, NC, USA), whereas to measure the metal concentrations in white clover roots and leaves, tissues were treated with concentrated nitric acid $(2.5 \mathrm{~mL})$ and $250 \mu \mathrm{L}$ hydrogen peroxide solution $\left(30 \% \mathrm{w} / \mathrm{w}\right.$ in $\left.\mathrm{H}_{2} \mathrm{O}\right)$ diluted in $2.250 \mathrm{~mL}$ double deionized water at $150{ }^{\circ} \mathrm{C}$ (Method Plant Material, US EPA 1996) in the above mentioned microwave oven [47]. Metal analysis of these solutions was carried out by electrothermal atomic absorption spectrometry (AAS), using the Thermo iCE 3400 instrument with Zeeman correction (Thermo Electron Manufacturing Ltd., Cambridge, UK). Quality assurance procedures including the analysis of reagent blanks and standard reference material, i.e., Montana II soil (NIST ${ }^{\circledR}$ 2711a, Sigma-Aldrich) and tomato leaves (NIST ${ }^{\circledR}$ 1573a, Sigma-Aldrich), for soil and plant samples, respectively, were performed in parallel. The recovery of $\mathrm{Zn}, \mathrm{Pb}$, and $\mathrm{Cd}$ was $90 \%-95 \%$. Data were expressed as mean \pm SD. They were analyzed by one-way analysis of variance (ANOVA) followed by the Duncan's multiple range test. Differences at $p<0.05$ were considered as statistically significant.

\subsection{Data Availability}

The partial $16 \mathrm{~S}$ rRNA gene sequences received from of all studied strains were deposited in the GenBank database under the accession numbers MN 943500-MN 943612.

\section{Results and Discussion}

\subsection{Taxonomic Identification and Genetic Analysis of Bacteria Associated with T. repens}

In order to search for novel heavy metal tolerant strains equipped with plant growth promotion properties and determining their taxonomic position, 113 endophytes from leaves, roots, and nodules of $T$. repens as well as bacteria from the T. repens rhizosphere, originating from three 70-100-year old $\mathrm{Zn}-\mathrm{Pb}$-rich waste heaps and a non-polluted reference grassland, were classified on the basis of $16 \mathrm{~S}$ rRNA gene Sanger sequence analysis (Figure 1).

Amplification of the 16S rRNA genes of the different isolates with $27 \mathrm{~F}$ and $1492 \mathrm{R}$ primers yielded products of about 1,300 bp. Identification of the isolates was performed by alignment of the 16S rRNA gene sequences with reference sequences available in the NCBI database using the BLAST algorithm. On this basis, the percentage of identical nucleotides in the 16S rRNA gene of tested isolates and reference bacteria, the endophytic and rhizospheric bacteria of $T$. repens were categorized as 31 species, members of 21 genera belonging to 13 families, 11 orders, and 4 phyla of the Bacteria domain (Figure 2). The most numerous phylum was that of the Proteobacteria, containing almost $45 \%$ of the isolates, represented predominantly by Enterobacteriales (38\%), Pseudomonadales (31\%), and Xanthomonadales (21\%) with Pantoea agglomerans (29\%), Pseudomonas putida (21\%), and Stenotrophomonas maltophilia $(100 \%)$, respectively. The phylum Firmicutes, comprising almost $40 \%$ of the isolates, was represented by strains belonging to the order Bacillales $(100 \%)$, belonging predominantly to the family Bacillaceae (97\%), represented mainly by the species Bacillus megaterium (39\%). The phylum Actinobacteria (12\%) was represented by bacteria of the order Micrococcales (83\%) and Actinomycetales (17\%). Among the Bacteroidetes, which comprised only $3 \%$ of the isolates, strains belonging to the order Flavobacteriales (70\%) were dominating, with the family Flavobacteriaceae (67\%), represented by Flavobacterium sp. and Chryseobacterium lathyri. 


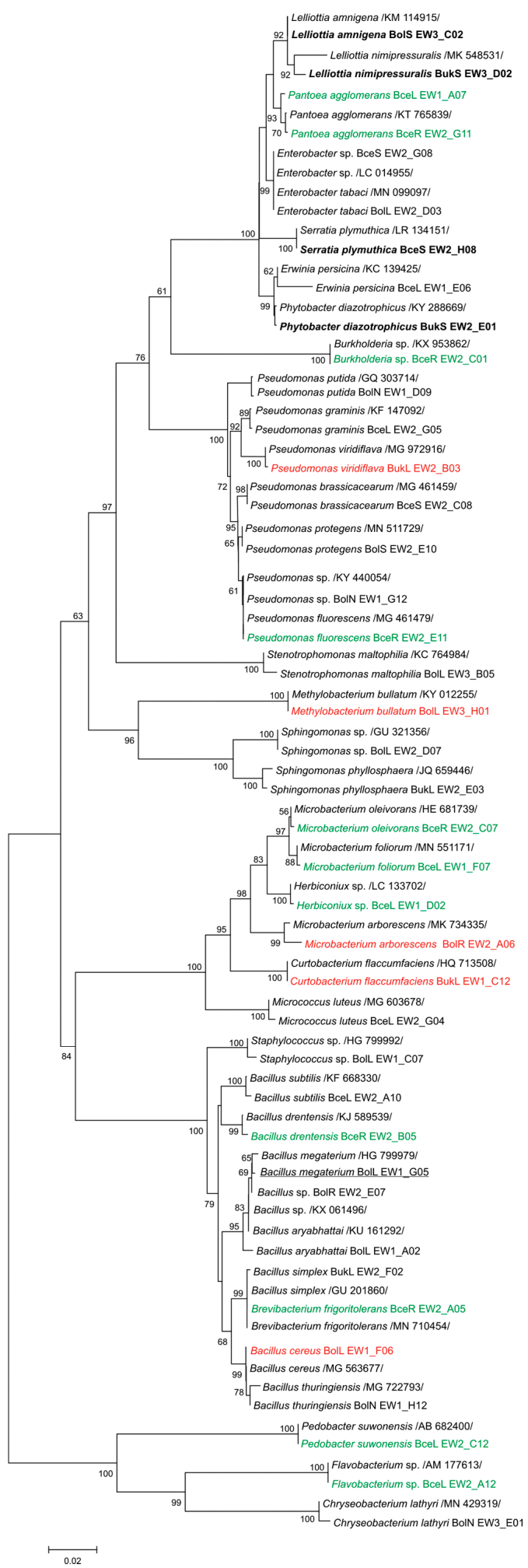

Figure 1. Phylogenetic Maximum Likelihood tree based on 900-bp 16S rRNA gene sequences showing the relationships of isolated bacteria and reference strains (GenBank database). Numbers at nods indicate levels of bootstrap support based on an analysis of 1000 resampled data sets. Accession numbers of reference strains of the studied strains used as representatives are shown in parentheses. The scale bar indicates the number of substitutions per site. Names of taxons detected as characteristic to waste heap conditions are marked in red, while those to reference ones are in green. Taxon names specific to the $T$. repens rhizosphere are in bold, while those characteristic to the host-plant tissues are underlined. 


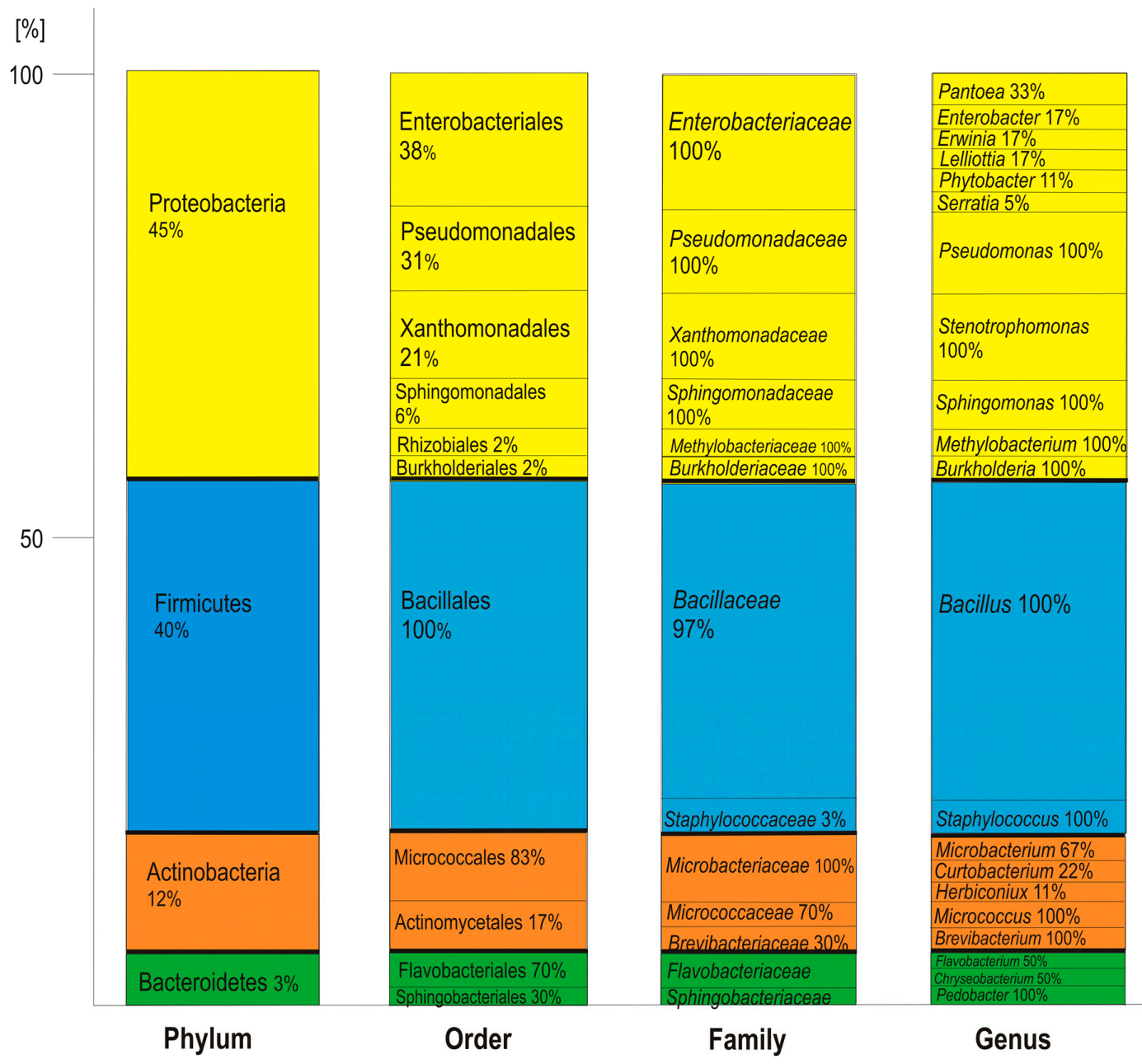

Figure 2. Percentages of in total 113 studied bacterial strains, identified on the basis of $16 \mathrm{~S}$ rRNA gene sequences, in the main taxonomic groups.

The rhizosphere as the "growth chamber" of distinct physicochemical conditions where i.a. carbon-rich molecules or biocontrol compounds influence the fitness of microbes, is the niche with the highest microbiome diversity [48], clearly higher than the endosphere microbiomes [49,50]. The rhizoplane can play a "critical gating" role [51], restricting endosphere community members to bind to root surfaces [52]. Exclusion of some specific bacterial groups might be a consequence of the host plant immune system activity [53]. The results show the occurrence of distinctive taxa specially between plant tissues and soil (Figure 3 and Figure S1). For example, Lelliottia amnigena was detected as a species exclusively occurring in soils. L. amnigena is a plant pathogen [54,55]. Therefore, its absence in plant tissues should be considered as advantageous and might be considered as a possible example of an adaptive mechanism to prevent the white clover from diseases. B. megaterium was detected only in plant tissues and was not found in soils. Sphingomonas sp. and S. phyllosphaerae were found exclusively in leaves, whereas Stenotrophomonas maltophilia was not detected in roots but was present in soils, leaves, and nodules. Taxa such as B. megaterium, Sphingomonas sp., and S. maltophilia show a wide range of distribution [56,57]. Their dissimilar presence in plant tissues might be due to differences in access to nutrients or specific traits of the host plant [58]. Moreover, it was shown that apart from rhizobia, which are permanent inhabitants of white clover root nodules [15,22,23], nodules are also inhabited by many other non-rhizobial bacterial taxa, e.g., Bacillus sp., Pseudomonas sp., Stenotrophomonas maltophilia, Micrococcus luteus, Erwinia persicina, and Chryseobacterium lathyri (Figure 3B). Muresu et al. [59] demonstrated that nodules of the legume plant Hedysarum sp. are also a niche for non-rhizobial inhabitants, e.g., Enterobacter cloaceae, Enterobacter kobei, Escherichia 
vulneris, Pantoea agglomerans, Leclercia adecarboxylata. Because co-inoculation of legumes by rhizobia and other bacterial species, e.g., Bacillus sp. obviously improved nodulation [60] and the availability of nitrogen [61], Sturz et al. [62] and Martínez-Hidalgo and Hirsch [25] suggested that non-pathogenic bacteria occurring sympatrically with rhizobia in nodules may influence a host plant beneficially. Such effective partnerships might be especially advantagous on the $\mathrm{Zn}-\mathrm{Pb}$ polluted waste heaps. White clover nodules from the Bolesław, Saturn, and Bukowno metalliferous areas harbor many taxa similar to those from nodules of plants growing on the non-polluted reference site; they are inhabited by Chryseobacterium sp., Stenotrophomonas sp., biosurfactant producing Bacillus sp., and Pseudomonas sp. (Figure 3), which are commonly used in bioremediation.
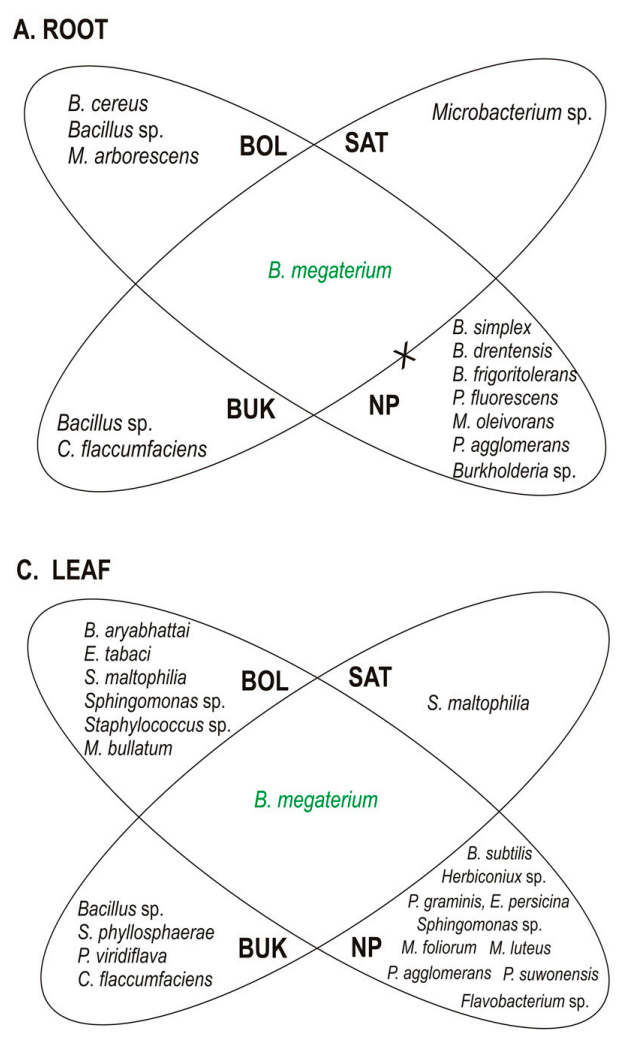

\section{B. NODULE}

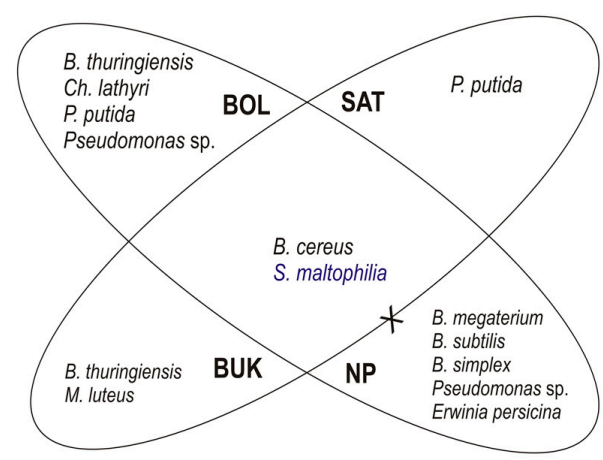

D. SOIL

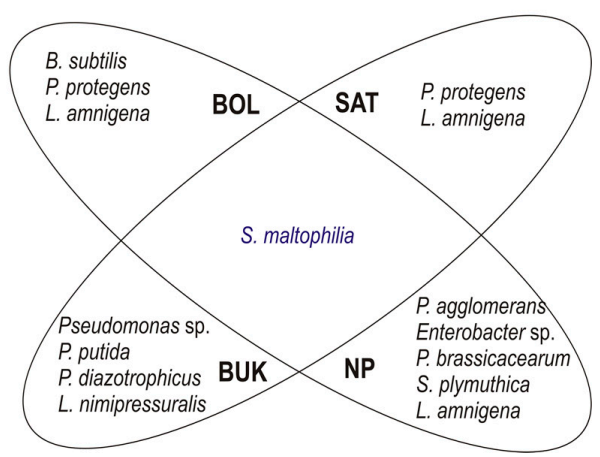

Figure 3. Shared and distinct bacterial taxa identified as root (A), nodule (B), and leaf (C) endophytes of T. repens and rhizosphere soil (D) originating from three metalliferous sites: Bolesław (BOL), Saturn (SAT), Bukowno (BUK), and the Bolestraszyce (NP) non-polluted reference site. Symbol X indices absence of common taxa.

A selective pressure of heavy metals towards the T. repens endophytic and rhizosphere bacterial communities from the waste heap in comparison to those from the reference area is obvious. The $\mathrm{U}$ Mann-Whitney test revealed a significantly higher $(p<0.0001)$ Shannon's diversity index in the reference samples from Bolestraszyce $\left(H^{\prime}=2.9532\right)$ in comparison with those from the three metal polluted waste heaps, Bolesław $\left(H^{\prime}=1.8181\right)$, Bukowno $\left(H^{\prime}=2.2310\right)$, and Saturn $\left(H^{\prime}=1.6521\right)$. The higher diversity of the communities from the non-polluted reference site corresponds with the significantly lower $\mathrm{Zn}, \mathrm{Pb}$, and $\mathrm{Cd}$ concentrations in the reference soil in comparison with the waste heap soils (Table 1). In leaves of $T$. repens from the reference grassland, besides B. megaterium, 10 different endophytic bacterial species were identified, compared to six from Bolesław, four from Bukowno, and one from Saturn (Figure 3). Taxa like Herbiconiux sp., Flavobacterium sp., Pedobacter suwonensis, Microbacterium foliorum were found exclusively in leaves of white clover originating from the reference site in Bolestraszyce, while Methylobacterium bullatum was detected only in leaves from Bolesław, and Pseudomonas viridiflava was identified only in leaves from Bukowno (Figure 3). 
In roots, Brevibacterium frigoritolerans, Bacillus drentensis, Pseudomonas fluorescens, Microbacterium oleivorans, Pantoea agglomerans, and Burkholderia sp. were found to be specific for T. repens from the Bolestraszyce reference site, whereas Bacillus cereus and Microbacterium arborescens were exclusive endophytes of roots from Bolesław, whereas Curtobacterium flaccumfaciens bacteria was found only in Bukowno. Bacillus subtilis, B. simplex, and E. persicina were spotted exclusively in T. repens root nodules from Bolestraszyce while Chryseobacterium lathyri, Pseudomonas putida were found only in nodules from Bolesław, and Micrococcus luteus only in nodules from Bukowno. In almost all investigated leaf and root microbial communities Bacillus megaterium appeared as a common taxon, and Stenotrophomonas maltophilia was found as a common species in soil and nodule communities of plants from metalliferous and non-metalliferous areas (Figure 3).

In order to identify the genotypes that could be potentially the most valuable for phytostabilization purposes, 16S rRNA gene sequences of all B. megaterium and S. maltophilia strains were identified and the relationship between individual strains was calculated and presented as Minimum Spanning Trees (MSTs) using the Arlequin 3.5 software package. Based on the 16S rRNA gene sequence analysis, the twenty investigated $B$. megaterium strains were assigned to seven genotypes with a sequence identity to each other of $96 \%-99 \%$. Genotypes $\mathrm{E}(f=0.15)$ and $\mathrm{F}(f=0.20)$ consist of strains isolated from tissues of white clover growing on both the waste heaps and non-polluted reference site, genotypes $\mathrm{A}$ $(f=0.1), \mathrm{B}(f=0.15), \mathrm{C}(f=0.30)$, and $\mathrm{G}(f=0.05)$ contain strains originating only from the waste heaps, whereas the genotype $\mathrm{D}(f=0.05)$ comprises exclusively strains from the Bolestraszyce reference area (Table S1). Strains of the genotype A, specific to the Bolesław waste heap, differed in their 16S rRNA sequence in one nucleotide from the genotype $\mathrm{D}$ strain, unique to the reference site. In turn, the bacteria of the genotype $\mathrm{D}$ differed in one nucleotide from the genotype $\mathrm{E}$ bacteria, which were found on all sites, and by one nucleotide from the genotype $G$ that was specific to the Bukowno waste heap, and in one $16 \mathrm{~S}$ rDNA nucleotide from the genotype $\mathrm{B}$ unique to the Bolesław waste heap. The bacteria of the genotype $B$ differed in one nucleotide from those belonging to genotype $C$, which was specific to metal-polluted waste heaps, and in one nucleotide from genotype $\mathrm{F}$ bacteria, which occurred on all studied sites (Figure 4).

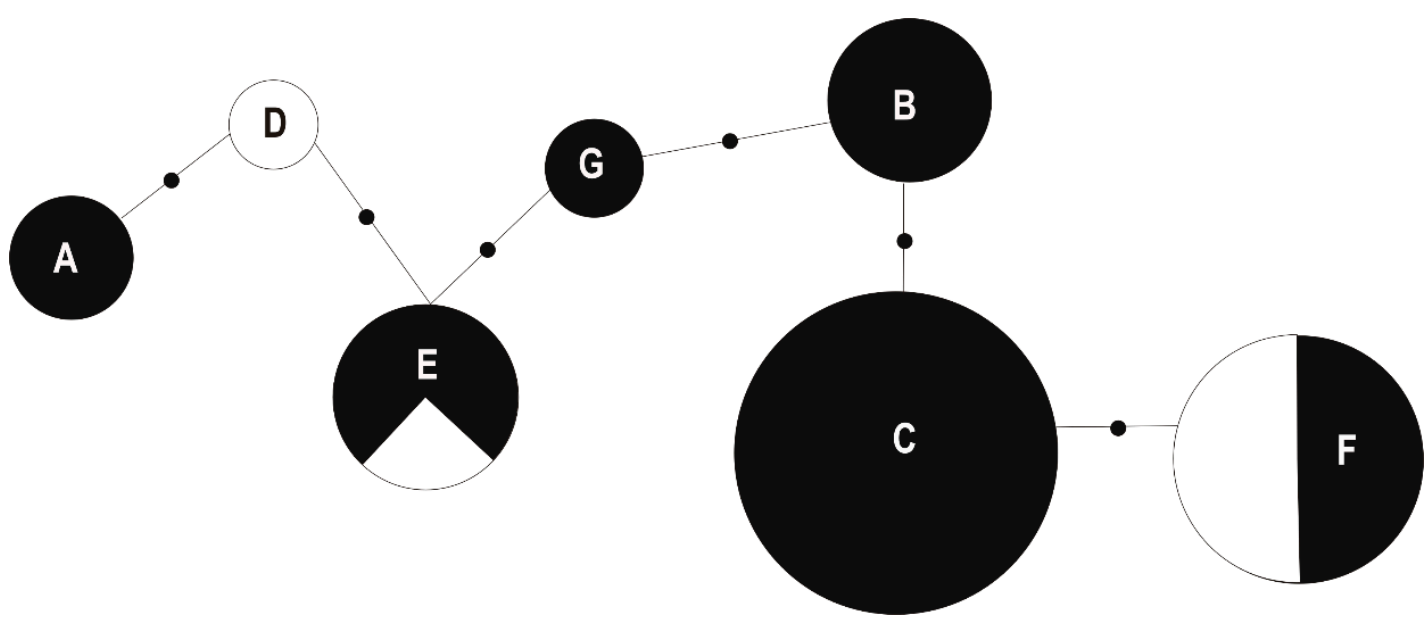

Figure 4. Minimum spanning tree (MST) based on a pairwise distance matrix computed on the basis of 900-bp 16S rRNA gene sequence analysis of studied genotypes (symbols A-G) of Bacillus megaterium strains derived from the Bolesław, Saturn, and Bukowno waste heaps (metalliferous) and Bolestraszyce non-polluted reference (non-metalliferous) area. The size of the circle corresponds to the genotype frequency. Small dots on the tree edges correspond to the number of nucleotide differences in 900-bp $16 \mathrm{~S}$ rRNA gene between nodes representing B. megaterium genotypes (A-G). Dark parts of the circles correspond to the frequency of $B$. megaterium strains with a given genotype in a metalliferous area. 
A comparative analysis of the $16 \mathrm{~S}$ rRNA gene of S. maltophilia strains allowed to distinguish 10 genotypes (Table S2). Two potential ancestor genotypes, genotypes $\mathrm{A}$ and $\mathrm{H}$ originating from calaminarian grasslands, gave three branches, and differed from each other by 12 nucleotides. The genotype $\mathrm{A}(f=0.154)$ differed from the genotypes $\mathrm{D}(f=0.154)$ and $\mathrm{B}(f=0.077)$, obtained from tissues of the white clover growing on calaminarian grassland, by six and five mutations, respectively. The genotype $\mathrm{D}$ differed from the unique to calaminarian land genotype $\mathrm{E}(f=0.077)$ in two mutations. The genotype $B$ differed from the waste heap originating genotypes $C(f=0.077)$ by five nucleotides, and $\mathrm{F}(f=0.077)$ by one nucleotide. The genotype $\mathrm{H}(f=0.077)$ differed from the calaminarian origin genotype $\mathrm{G}(f=0.154)$ by 7 mutations, and from the non-metalliferous origin genotype $\mathrm{J}(f=0.077)$ by 6 nucleotides, and 9 mutations from the genotype I $(f=0.077)$. Genotypes $\mathrm{G}-\mathrm{J}$, which were obtained from soil, carried in their 16S rRNA gene more mutations than the other identified genotypes that were isolated from tissues of white clover. The relationships between the analyzed 16S rRNA genotypes of the studied B. megaterium and S. maltophilia strains originating from the waste heap and the non-polluted reference populations are presented as a MST in Figure 5.

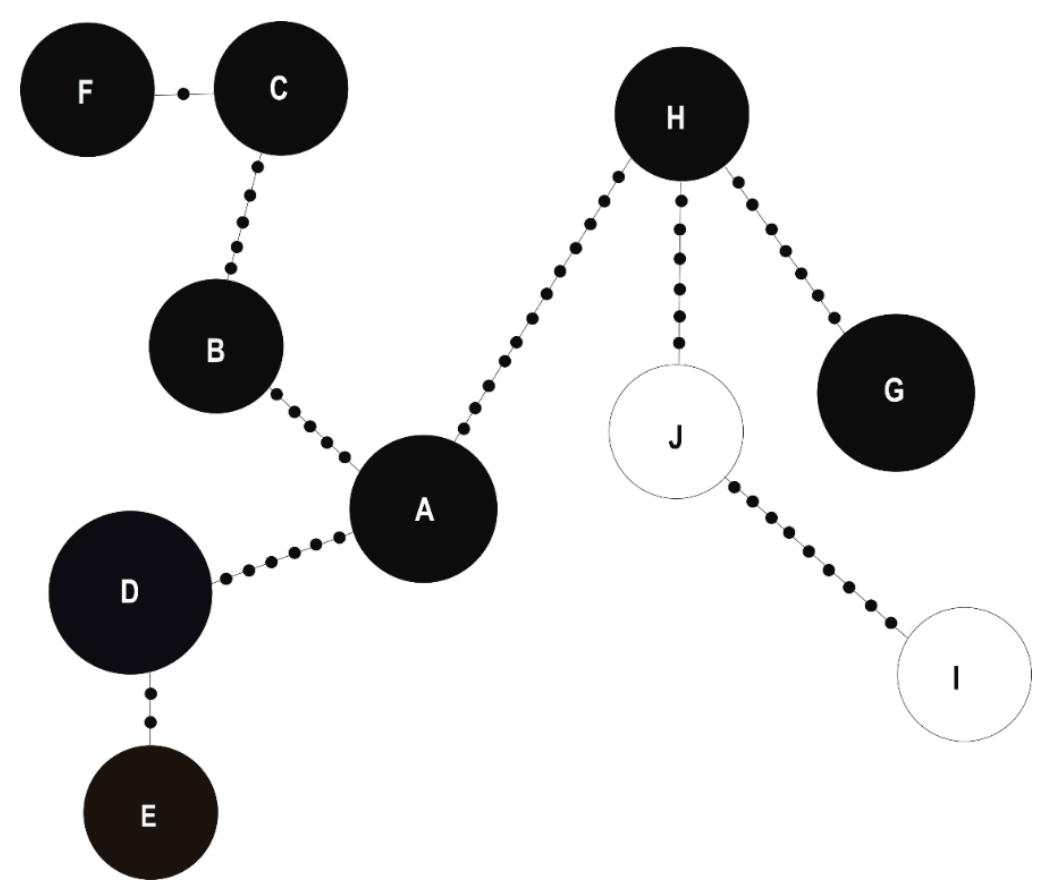

Figure 5. Minimum spanning tree (MST) based on a pairwise distance matrix computed on the basis of 900-bp 16S rRNA gene sequence analysis of studied genotypes (symbols A-J) of Stenotrophomonas maltophilia strains derived from the Bolesław, Saturn, and Bukowno waste heaps (metalliferous) and Bolestraszyce non-polluted (non-metalliferous) areas. The size of the circle corresponds to the genotype frequency in the whole sample. Small dots on the tree edges correspond to the differences in the number of different nucleotides in 900-bp 16S rRNA gene between nodes representing S. maltophilia genotypes (A-J). Dark parts of the circles correspond to the frequency of S. maltophilia strains with a given genotype in a metalliferous area.

\subsection{In Vitro Testing of Plant Growth Promotion Traits and Heavy Metal Tolerance}

In vitro testing of the 113 bacterial strains for their ability to synthesize auxins, siderophores, organic acids, acetoin, their ACC-deaminase activity, phosphorus solubilization, and nitrogen fixation capacities found that many of them exhibit plant growth promotion (PGP) properties (Table S3). Over $11 \%$ of the isolated bacterial strains were positive for all seven PGP traits that were investigated, about $35 \%$ of the strains showed positive for six traits, $34 \%$ for five, $12 \%$ for four, and $8 \%$ for three traits. The taxonomic distribution of the plant growth promotion abilities and metal tolerance at the genus level, are presented in Figure S2. 
More than $60 \%$ of the studied strains were able to synthesize auxins, siderophores, acetoin, exhibited ACC-deaminase activity and could solubilize phosphorus; $40 \%-58 \%$ of strains demonstrated diazotrophic activity, while $20 \%-37 \%$ of the isolates produced organic acids (Figure 6).

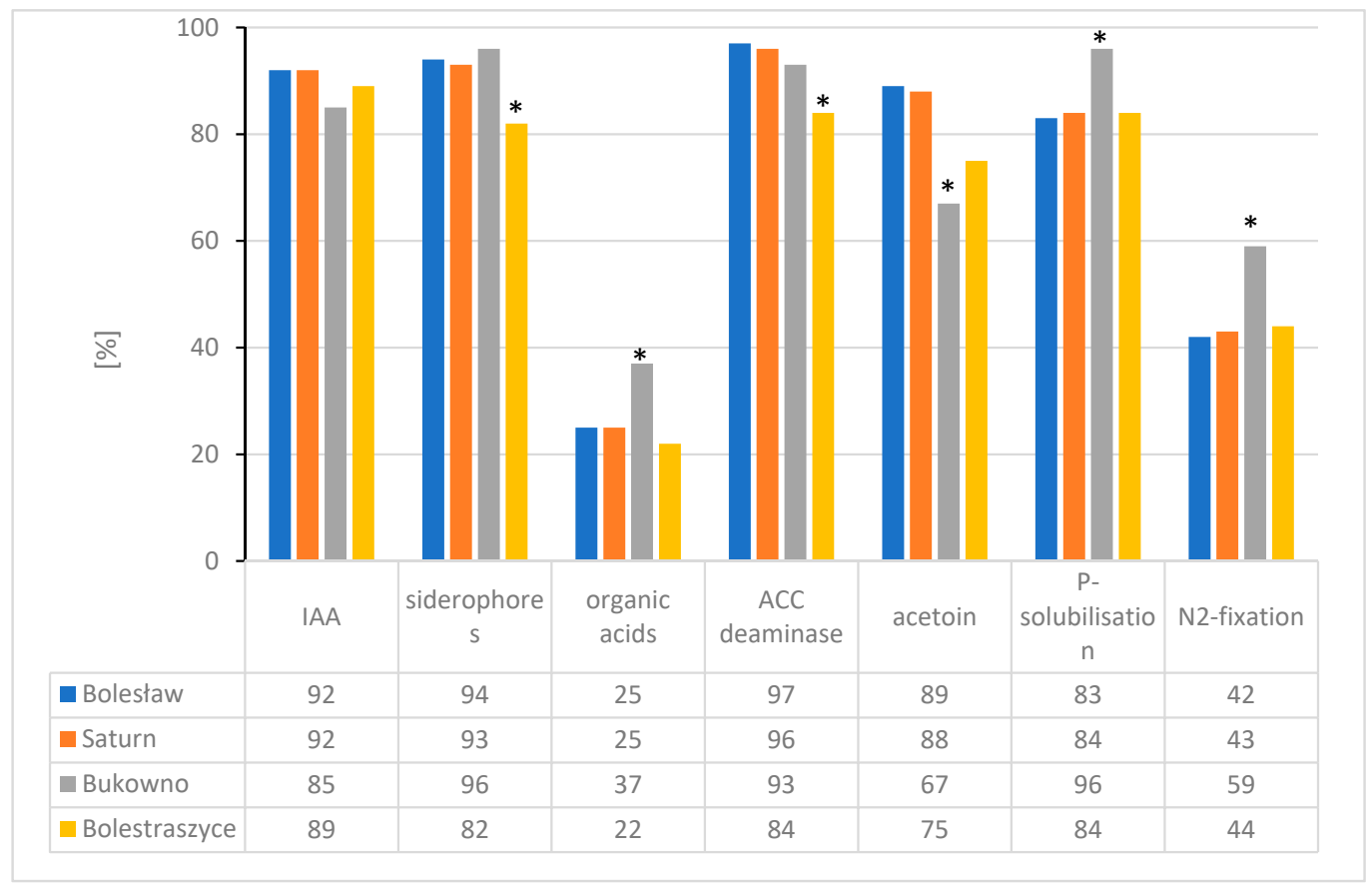

Figure 6. Percentages of strains isolated from rhizosphere soil and tissues of T. repens originating from the Bolesław, Saturn, and Bukowno metalliferous waste heaps and the Bolestraszyce non-polluted reference area demonstrating the tested in vitro plant growth promotion traits. The asterisks indicate statistically significant differences at $p<0.05$.

The latter trait leads to acidification of the soil and is a main mechanism for solubilization of inorganic phosphorus compounds that are unavailable to plants [63]. Phosphorus solubilization and fixation of atmospheric nitrogen by plant-associated bacteria are important properties that provide nutritional support for the host plants [64-66]. Synthesis of ACC-deaminase supports plant growth and development in stressful conditions by lowering the ethylene levels [67]. At low concentrations, auxins produced by bacteria can stimulate the elongation of primary roots and formation of root hairs, enhance the nutrients uptake by the host plant, and stimulate the production of root exudates $[18,68,69]$. Additionally, the capability of bacteria to synthesize siderophores is a highly advantageous trait, because microbes can facilitate the uptake of iron by their host. The availability of iron for the plants indeed is mostly limited [70]. Acetoine synthesis by bacteria can promote plant growth by stimulating root development and increasing the resistance of the plants against pathogens and drought stress [71].

When comparing the bacterial communities originating from the metal-polluted and non-polluted areas, differences in percentages of bacterial strains demonstrating PGP traits in vitro were observed (Figure 6). Compared to strains from the non-polluted Bolestraszyce reference site, significantly more strains of waste heap origin were able to produce siderophores, acetoin and to synthesize ACC-deaminase. Higher percentages of bacterial isolates from the Bukowno waste heap demonstrated phosphorus solubilization, nitrogen fixation, and organic acids production $(96 \%, 59 \%$, and 37\%, respectively) in comparison to strains from the reference area $(84 \%, 44 \%$, and $22 \%$, respectively), while the percentages of strains originating from the Bolesław and Saturn waste heaps and the reference site in Bolestraszyce producing auxins and organic acids, solubilizing phosphorus, and fixing nitrogen were similar (Figure 6). The occurrence of positive correlations between metal induced oxidative stress and high levels of bacteria-born phytohormones, ability to produce siderophores and other PGP traits 
of bacteria, and the high plant dry mass and high primary root length, is notable [72,73]. It was also earlier documented that, in the presence of metals, acetoin produced by bacteria improves the oxidative stress resistance, the ACC-deaminase activity is higher [74-76], IAA synthesis is higher and this can promote the formation of lateral and adventitious roots, and as a result can enhance mineral uptake by plants $[18,68,69,77]$.

Results obtained during the present study indicate that B. megaterium and S. maltophilia were the most numerous representatives of the dominating phylum Proteobacteria, and were common taxa of both metallicolous and non-metallicolous bacterial communities associated with T. repens (Figure 3). All B. megaterium and S. maltophilia strains could solubilize phosphorus and synthesize ACC deaminase. Only one strain BolR EW3_A03, representing the genotype C, isolated from white clover roots from Bolesław, showed positive results for all seven PGP traits that were tested, $69 \%$ of the strains were positive for six of them, $13 \%$ for five, and $6 \%$ for four plant growth promoting traits. B. megaterium is an ubiquitous organism, which was already mentioned as an endophyte of plants [78]. Its plant growth promoting traits, e.g., phosphate solubilization, nitrogen fixation, and indole acetic acid (IAA) production were described before [79]. Bacillus megaterium R181 was reported as an effective stimulator of corn and wheat growth [78]. Moreover, B. megaterium synthesizes antibiotic-type compounds, for example a large group of lipopeptides of antagonistic activity similar to surfactins, lichenysins, itrurinA, and fengycins, which is of high importance in preventing plants against diseases, and the potential usage to improve plant growth [80-82].

All studied S. maltophilia strains were able to synthesize siderophores and auxins. Only strain BolN EW3_B03, representing the genotype E, isolated from nodules of T. repens growing on the Bolesław waste heap, showed positive for all tested PGP traits; 30\% of S. maltophilia isolates were positive for six of the traits, $40 \%$ for five, and 10\% for four tested PGP traits. As already mentioned in earlier studies $[83,84]$, the PGP properties of S. maltophilia point to a biotechnological potential of these strains. Amongst others, it was reported that due to its production of proteolytic enzymes and through induction of pathogenesis related (PR) genes, S. maltophilia strain PD4560 can be used as biocontrol agent against Ralstonia solanacearum in sustainable agriculture [83]. Singh and Jha [84] also demonstrated that, under abiotic stress, S. maltophilia exhibits plant growth promoting (PGP) traits including synthesis of ACC deaminase, gibberellic acid, indole acetic acid (IAA), siderophores, and is able to solubilize inorganic phosphates.

Of the 113 isolates of the rhizosphere and endosphere of T. repens, about $65 \%$ showed co-tolerance to $\mathrm{Cd}, \mathrm{Zn}, \mathrm{Cu}$ and $\mathrm{Pb}$ (Table S3); this group involved also Bacillus megaterium BolR EW3_A03 and Stenotrophomonas maltophilia BolN EW3_B03.

\section{Conclusions}

T. repens associated bacteria originating from three $70-100$-year old $\mathrm{Zn}-\mathrm{Pb}$ rich waste heaps, Bolesław, Saturn, and Bukowno showed some species specificity at the level of: (i) the 'compartment', e.g., S. maltophilia was isolated from soils, leaves, and nodules but not from roots, while B. megaterium was not found in soil but in plant tissues; and (ii) the type of site, i.e., Methylobacterium bullatum or Pseudomonas viridiflava were detected in plant tissues of waste heap origin, while Herbiconiux sp. or Flavobacterium sp. were found in tissues of white clover originating from the non-polluted reference site. Furthermore, concerning the potential plant growth promotion traits, differences were observed between strains originating from waste heaps and those from the unpolluted reference area. In general, more strains of waste heap origin showed the ability to produce siderophores, acetoin and to synthesize ACC-deaminase in comparison with those from the reference site. Among the $65 \%$ of strains that were co-tolerating $\mathrm{Cd}, \mathrm{Zn}, \mathrm{Cu}$, and $\mathrm{Pb}$, two strains, B. megaterium BolR EW3_A03 and S. maltophilia BolN EW3_B03, which showed positive for all in vitro tested plant growth promotion traits (i.e., phosphorus solubilization, nitrogen fixation, synthesis of organic acids, siderophores synthesis, IAA synthesis, ACC deaminase activity, and acetoin synthesis) can be assumed as the most promising ones for application in phytostabilization of $\mathrm{Zn}, \mathrm{Pb}$ and $\mathrm{Cd}$ polluted areas. 
Supplementary Materials: The following are available online at http://www.mdpi.com/2223-7747/9/8/1002/s1, Table S1: Variable sites in 900-bp long fragments of $16 \mathrm{~S}$ rRNA gene of Bacillus megaterium genotypes from the $\mathrm{Zn}-\mathrm{Pb}$ rich waste heaps in Bolesław, Saturn, and Bukowno and the non-metalliferous reference area in Bolestraszyce; Table S2: Variable sites in 900-bp long fragments of 16S rRNA gene of Stenotrophomonas maltophilia genotypes from the $\mathrm{Zn}-\mathrm{Pb}$ rich waste heaps in Bolesław, Saturn, and Bukowno and the non-metalliferous reference area in Bolestraszyce; Table S3: Potential plant-growth promoting traits of strains isolated from the endosphere tissues (i.e., roots, nodules, and leaves) and the rhizosphere soil of T. repens originating from the Bolesław, Saturn, and Bukowno waste heaps, and the non-metalliferous reference area in Bolestraszyce. Abbreviations: IAA-indole-3-acetic acid synthesis, sid—siderophores production, org acids—organic acids production, ACCD—deaminase ACC activity, acet-acetoin production, $\mathrm{P}$ solub-phosphorus solubilization, $\mathrm{N}$-fix-atmospheric nitrogen fixation. Figure S1: Relative abundance of the cultivable strains displaying in vitro PGP abilities or metal tolerance $(0.4 \mathrm{mMCd}, 0.6$ $\mathrm{mM} \mathrm{Zn}, 0.4 \mathrm{mM} \mathrm{Cu}$ ), distributed over the different compartments, leaf endosphere, nodule, root endosphere and rhizosphere soil of T. repens; Figure S2: Relative abundance of the cultivable strains grouped per PGP trait and metal tolerance $(0.4 \mathrm{mM} \mathrm{Cd}, 0.6 \mathrm{mM} \mathrm{Zn}, 0.4 \mathrm{mM} \mathrm{Cu})$ and shown per compartment of T. repens.

Author Contributions: Conceptualization, E.O. and J.V.; methodology, S.T., V.I., T.W.; software, S.T. and E.O.; validation, M.W., W.M. and I.S.; formal analysis, S.T., E.O., T.W.; investigation, E.O., S.T.; resources, E.O.; data curation, S.T., E.O.; writing-original draft preparation, E.O. and S.T.; writing-review and editing, W.M., J.V., M.W., T.W., and I.S.; visualization, E.O., S.T., V.I.; supervision, J.V., W.M.; project administration, E.O., S.T.; funding acquisition, E.O. and J.V. All authors have read and agreed to the published version of the manuscript.

Funding: This research was funded by BOF Special Research Fund to E.O. from Hasselt University. Support was also provided by the UHasselt Methusalem project 08M03VGRJ.

Acknowledgments: The authors would like to express their gratitude to Ann Wijgaerts, Carine Put, Edyta Żuk-Kempa, Barbara Łaszkiewicz-Tiszczenko for assistance in laboratory work, and Krzysztof Oleński for support in collecting the material used in the study.

Conflicts of Interest: The authors declare no conflict of interest. The funders had no role in the design of the study; in the collection, analyses, or interpretation of data; in the writing of the manuscript, or in the decision to publish the results.

\section{References}

1. Fuentes, A.; Almonacid, L.; Ocampo, J.A.; Arriagada, C. Synergistic interactions between a saprophytic fungal consortium and Rhizophagus irregularis alleviate oxidative stress in plants grown in heavy metal contaminated soil. Plant Soil 2016, 407, 355-366. [CrossRef]

2. Etesami, H. Bacterial mediated alleviation of heavy metal stress and decreased accumulation of metals in plant tissues: Mechanisms and future prospects. Ecotoxicol. Environ. Saf. 2018, 147, 175-191. [CrossRef] [PubMed]

3. Ashraf, M.A.; Hussain, I.; Rasheed, R.; Iqbal, M.; Riaz, M.; Arif, M.S. Advances in microbe-assisted reclamation of heavy metal contaminated soils over the last decade: A review. J. Environ. Manag. 2017, 198, 132-143. [CrossRef] [PubMed]

4. Koul, B.; Taak, P. Chemical Methods of Soil Remediation. In Biotechnological Strategies for Effective Remediation of Polluted Soils; Koul, B., Taak, P., Eds.; Springer: Singapore, 2018; pp. 77-84.

5. Vangronsveld, J.; Herzig, R.; Weyens, N.; Boulet, J.; Adriaensen, K.; Ruttens, A.; Thewys, T.; Vassilev, A.; Meers, E.; Nehnelajova, E.; et al. Phytoremediation of contaminated soils and groundwater: Lessons from the field. Environ. Sci. Poll. Res. 2009, 16, 765-794. [CrossRef]

6. Weyens, N.; van der Lelie, D.; Taghavi, S.; Vangronsveld, J. Phytoremediation: Plant-endophyte partnerships take the challenge. Curr. Opin. Biotechnol. 2009, 20, 248-254. [CrossRef]

7. Rajkumar, M.; Sandhya, S.; Prasad, M.N.V.; Freitas, H. Perspectives of plant-associated microbes in heavy metal phytoremediation. Biotechnol. Adv. 2012, 30, 1562-1574. [CrossRef]

8. Shah, V.; Daverey, A. Phytoremediation: A multidisciplinary approach to clean up heavy metal contaminated soil. Environ. Technol. Innov. 2020, 18, 100774. [CrossRef]

9. Wójcik, M.; Gonnelli, C.; Selvi, F.; Dresler, S.; Rostański, A.; Vangronsveld, J. Metallophytes of serpentine and calamine soils-Their unique ecophysiology and potential for phytoremediation. Adv. Bot. Res. 2017, 83, 1-42.

10. Ernst, W.H.O. Phytoextraction of mine waste-Options and impossibilities. Chem. Geochem. 2005, 65, $29-42$. [CrossRef] 
11. Vangronsveld, J.; Sterckx, J.; Van Assche, F.; Clijsters, H. Rehabilitation studies on an old non-ferrous waste dumping ground: Effects of revegetation and metal immobilization by beringite. J. Geochem. Explor. 1995, 52, 221-229. [CrossRef]

12. Vangronsveld, J.; Van Assche, F.; Clijsters, H. Reclamation of a bare industrial area contaminated by non ferrous metals-In situ metal immobilization and revegetation. Environ. Pollut. 1995, 87, 51-59. [CrossRef]

13. Tam, N.F.Y.; Wong, Y.S. Effectiveness of bacterial inoculum and mangrove plants on remediation of sediment contaminated with polycyclic aromatic hydrocarbons. Mar. Poll. Bull. 2008, 57, 716-726. [CrossRef] [PubMed]

14. Silver, S.; Phung, L.T. Bacterial heavy metal resistance: New surprises. Ann. Rev. Microbiol. 1996, 50, 753-789. [CrossRef] [PubMed]

15. Oleńska, E.; Małek, W. Sequence analysis of hypothetical lysine exporter genes of Rhizobium leguminosarum bv. trifolii from calamine old waste heaps and their evolutionary history. Curr. Microbiol. 2013, 66, 493-498. [PubMed]

16. Weyens, N.; van der Lelie, D.; Taghavi, S.; Newman, L.; Vangronsveld, J. Exploiting plant-microbe partnerships to improve biomass production and remediation. Trends Biotechnol. 2009, 27, 591-598. [CrossRef] [PubMed]

17. Mishra, J.; Singh, R.; Arora, N.K. Alleviation of heavy metal stress in plants and remediation of soil by rhizosphere microorganisms. Front. Microbiol. 2017, 8, 1706. [CrossRef]

18. Glick, B.R. Using soil bacteria to facilitate phytoremediation. Biotechnol. Adv. 2010, 28, 367-374. [CrossRef]

19. Oleńska, E.; Małek, W.; Wójcik, M.; Swiecicka, I.; Thijs, S.; Vangronsveld, J. Beneficial features of plant growth-promoting rhizobacteria for improving plant growth and health in challenging conditions: A methodical review. Sci. Total Environ. 2020, 743, 140682. [CrossRef]

20. Sessitsch, A.; Kuffner, M.; Kidd, P.; Vangronsveld, J.; Wenzel, W.W.; Falmann, K.; Puschenreiter, M. The role of plant-Associated bacteria in the mobilization and phytoextraction of trace elements in contaminated soils. Soil Biol. Biochem. 2013, 60, 182-194. [CrossRef]

21. Sánchez-López, A.S.; Pintelon, I.; Stevens, V.; Imperato, V.; Timmermans, J.-P.; González-Chávez, C.; Carrillo-González, R.; Van Hamme, J.; Vangronsveld, J.; Thijs, S. Seed endophyte microbiome of Crotalaria pumila unpeeled: Identification of plant-beneficial Methylobacteria. Int. J. Mol. Sci. 2018, 19, 291. [CrossRef]

22. Oleńska, E.; Małek, W. Genetic differentiation of Trifolium repens microsymbionts deriving from $\mathrm{Zn}-\mathrm{Pb}$ waste-heap and control area in Poland. J. Basic Microbiol. 2015, 55, 462-470. [CrossRef] [PubMed]

23. Oleńska, E.; Małek, W. Genomic polymorphism of Trifolium repens root nodule symbionts from heavy metal-abundant 100-year-old waste heap in southern Poland. Archiv. Microbiol. 2019, 201, 1405-1414. [CrossRef] [PubMed]

24. Bidar, G.; Garçon, G.; Pruvot, C.; Dewaele, D.; Cazier, F.; Douay, F.; Shirali, P. Behavior of Trifolium repens and Lolium perenne growing in a heavy metal contaminated field: Plant metal concentration and phytotoxicity. Environ. Pollut. 2007, 147, 546-553. [CrossRef] [PubMed]

25. Martínez-Hildago, P.; Hirsch, A.M. The nodule microbiome: N2-Fixing rhizobia do not live alone. Phytobiomes 2017, 1, 70-82. [CrossRef]

26. Kalita, M.; Małek, W.; Coutinho, T.A. Putative novel Bradyrhizobium and Phyllobacterium species isolated from root nodules of Chamaecytisus ruthenicus. Syst. Appl. Microbiol. 2020, 43, 126056. [CrossRef]

27. Eevers, N.; Gielen, M.; Sánchez-López, A.; Jaspers, S.; White, J.C.; Vangronsveld, J.; Weyens, N. Optimization of isolation and cultivation of bacterial endophytes through addition of plant extract to nutrient media. Microb. Biotechnol. 2015, 8, 707-715. [CrossRef]

28. Imperato, V.; Portillo-Estrada, M.; McAmmond, B.M.; Douwen, Y.; Van Hamme, J.D.; Gawroński, S.W.; Vangronsveld, J.; Thijs, S. Genomic diversity of two hydrocarbon-degrading and plant growth-promoting Pseudomonas species isolated from the oil field of Bóbrka (Poland). Genes 2019, 10, 443. [CrossRef]

29. Reasoner, D.J.; Geldreich, E.E. A new medium for the enumeration and subculture of bacteria from potable water. Appl. Environ. Microbiol. 1985, 49, 1-7. [CrossRef]

30. Weisburg, W.; Barns, S.M.; Pelletier, D.; Lane, D.J. 16S ribosomal DNA amplification for phylogenetic study. J. Bacteriol. 1991, 173, 697-703. [CrossRef]

31. Kearse, M.; Moir, R.; Wilson, A.; Stones-Havas, S.; Cheung, M.; Sturrock, S.; Buxton, S.; Cooper, A.; Markowitz, S.; Duran, C.; et al. Geneious Basic: An integrated and extendable desktop software platform for the organization and analysis of sequence data. Bioinformatics 2012, 28, 1647-1649. [CrossRef] 
32. Tamura, K.; Stecher, G.; Peterson, D.; Filipski, A.; Kumar, S. MEGA6: Molecular Evolutionary Genetics Analysis Version 6.0. Mol. Biol. Evol. 2013, 30, 2725-2729. [CrossRef] [PubMed]

33. Spada, E.; Sagliocca, L.; Sourdis, J.; Garbuglia, A.R.; Poggi, V.; De Fusco, C.; Mele, A. Use of the minimum spanning tree model for molecular epidemiological investigation of a nosocomial outbreak of hepatitis C virus infection. J. Clin. Microbiol. 2004, 42, 4230-4236. [CrossRef] [PubMed]

34. Excoffier, L.; Lischner, H.E.L. Arlequin suite ver. 3.5: A new series of programs to perform population genetics analyses under Linux and Windows. Mol. Ecol. Res. 2010, 10, 564-567. [CrossRef] [PubMed]

35. Seguin, P.; Graham, P.H.; Sheaffer, C.C.; Ehlke, N.J.; Russelle, M.P. Genetic diversity of rhizobia nodulating Trifolium ambiguum in North America. Can. J. Microbiol. 2001, 47, 81-85. [CrossRef] [PubMed]

36. Farooq, F.T.; Vessey, J.K. Genetic diversity of Bradyrhizobium japonicum with soybean growing regions of the north-eastern Great Plains of North America as determined by REP-PCR and ERIC-PCR profiling. Symbiosis 2009, 48, 131-142. [CrossRef]

37. Pikovskaya, R.I. Mobilization of phosphorus in soil connection with the vital activity of some microbial species. Microbiology 1948, 17, 362-370.

38. Nautiyal, C.S. An efficient microbiological growth medium for screening phosphate solubilizing microorganisms. FEMS Microbiol. Lett. 1999, 170, 265-270. [CrossRef]

39. Xie, G.H.; Cui, Z.; Yu, J.; Yan, J.; Hai, W.; Steinberger, Y. Identification of nif genes in N2-fixing bacterial strains isolated from rice fields along the Yangtze River Plain. J. Basic Microbiol. 2006, 46, 56-63. [CrossRef]

40. Cunningham, J.E.; Kuiack, C. Production of citric and oxalic acids and solubilization of calcium phosphate by Penicillium bilaii. Appl. Environ. Microbiol. 1992, 58, 1451-1458. [CrossRef]

41. Schwyn, B.; Neilands, J. Universal chemical assay for the detection and determination of siderophores. Anal. Biochem. 1987, 160, 47-56. [CrossRef]

42. Schlegel, H.; Gottschalk, G.; Von Bartha, R. Formation and utilization of poly- $\beta$-hydroxybutyric acid by knallgas bacteria (Hydrogenomonas). Nature 1961, 191, 463-465. [CrossRef] [PubMed]

43. Gordon, S.A.; Weber, R.P. Colorimetric estimation of indole-acetic acid. Plant Physiol. 1951, 26, $192-195$. [CrossRef] [PubMed]

44. Patten, C.L.; Glick, B.R. Role of Pseudomonas putida indoleacetic acid in development of host plant root system. Appl. Environ. Microbiol. 2002, 68, 3795-3801. [CrossRef] [PubMed]

45. Belimov, A.A.; Hontzeas, N.; Safronova, V.I.; Demchinskaya, S.V.; Piluzza, G.; Bullitta, S.; Glick, B.R. Cadmium-tolerant plant growth-promoting bacteria associated with the roots of Indian mustard (Brassica juncea L. Czern.). Soil Biol. Biochem. 2005, 37, 241-250. [CrossRef]

46. Romick, T.L.; Fleming, H.P. Acetoin production as an indicator of growth and metabolic inhibition of Listeria monocytogenes. J. Appl. Microbiol. 1998, 84, 18-24. [CrossRef]

47. Włostowski, T.; Kozłowski, P.; Łaszkiewicz-Tiszczenko, B.; Oleńska, E. Cadmium accumulation and pathological alterations in the midgut gland of terrestrial snail Helix pomatia L. from a zinc smelter area: Role of soil pH. Bull. Environ. Contam. Toxicol. 2016, 96, 484-489. [CrossRef]

48. Liu, H.; Carvalhais, L.C.; Crawford, M.; Singh, E.; Dennis, P.G.; Pieterse, C.M.J.; Schenk, P.M. Inner plant values: Diversity, colonization and benefits from endophytic bacteria. Front. Microbiol. 2017, 8, 2552. [CrossRef]

49. Liu, H.; Carvalhais, L.C.; Schenk, P.M.; Dennis, P.G. Effects of jasmonic acid signalling on the wheat microbiome differ between body sites. Sci. Rep. 2017, 7, 41766. [CrossRef]

50. Bulgarelli, D.; Rott, M.; Schlaeppi, K.; Ver Loren van Themaat, E.; Ahmadinejad, N.; Assenza, F.; Rauf, P.; Huettel, B.; Reinhardt, R.; Schmelzer, E.; et al. Revealing structure and assembly cues for Arabidopsis root-inhabiting bacterial microbiota. Nature 2012, 488, 91-95. [CrossRef]

51. Edwards, J.; Johnson, C.; Santos-Medellín, C.; Lurie, E.; Podishetty, N.K.; Bhatnagar, S.; Eisen, J.A.; Sundaresan, V. Structure, variation, and assembly of the root associated microbiome of rice. Proc. Natl. Acad. Sci. USA 2015, 112, E911-E920. [CrossRef]

52. Reinhold-Hurek, B.; Bünger, W.; Burbano, C.S.; Sabale, M.; Hurek, T. Roots shaping their microbiome: Global hotspots for microbial activity. Annu. Rev. Phytopathol. 2015, 53, 403-424. [CrossRef] [PubMed]

53. Lundberg, D.S.; Lebeis, S.L.; Paredes, S.H.; Yourstone, S.; Gehring, J.; Malfatti, S.; Tremblay, J.; Engelbrektson, A.; Kunin, V.; Del Rio, T.G.; et al. Defining the core Arabidopsis thaliana root microbiome. Nature 2012, 488, 86-90. [CrossRef] [PubMed] 
54. Brady, C.; Cleenwerck, I.; Venter, S.; Coutinho, T.; De Vos, P. Taxonomic evaluation of the genus Enterobacter based on multilocus sequence analysis (MLSA). Syst. Appl. Microbiol. 2013, 36, 309-319. [CrossRef] [PubMed]

55. Liu, S.; Tang, Y.; Wang, D.; Lin, N.; Zhou, J. Identification and characterization of a new Enterobacter onion bulb decay caused by Lelliottia amnigena in China. Appl. Micro. 2016, 2, 2. [CrossRef]

56. Leys, N.M.E.J.; Ryngaert, A.; Bastiaens, L.; Verstraete, W.; Top, E.M.; Springael, D. Occurrence and phylogenetic diversity of Sphingomonas strains in soils contaminated with polycyclic aromatic hydrocarbons. Appl. Environ. Microbiol. 2004, 70, 1944-1955. [CrossRef]

57. Logan, N.A.; De Vos, P. Bacillus. In Bergey's Manual of Systematics of Archaea and Bacteria; Garrity, G.M., Ed.; John Wiley \& Sons, Inc.: Hoboken, NJ, USA, 2009; p. 41.

58. Kandel, S.L.; Joubert, P.M.; Doty, S.L. Bacterial endophyte colonization and distribution within plants. Microorganisms 2017, 5, 77. [CrossRef]

59. Muresu, R.; Polone, E.; Sulas, L.; Baldan, B.; Tondello, A.; Delogu, G.; Cappuccinelli, P.; Alberghini, S.; Benhizia, Y.; Benhizia, H.; et al. Coexistence of predominantly nonculturable rhizobia with diverse, endophytic bacterial taxa within nodules of wild legumes. FEMS Microbiol. Ecol. 2008, 63, 383-400. [CrossRef]

60. Schwartz, A.N.; Ortiz, I.; Maymon, M.; Herbold, C.W.; Fujishige, N.A.; Vijanderan, J.A.; Villella, W.; Hanamoto, K.; Diener, A.; Sanders, E.R.; et al. Bacillus simplex-A little known PGPB with anti-fungal activity-Alters Pea legume root architecture and nodule morphology when coinoculated with Rhizobium leguminosarum bv. viciae. Agronomy 2013, 3, 595-620. [CrossRef]

61. Rajendran, G.; Patel, M.H.; Joshi, S.J. Isolation and characterization of nodule-associated Exiguobacterium sp. from the root nodules of fenugreek (Trigonella foenum-graecum) and their possible role in plant growth promotion. Int. J. Microbiol. 2012, 2012, 693982. [CrossRef]

62. Sturz, A.V.; Christie, B.R.; Nowak, J. Bacterial endophytes: Potential role in developing sustainable system of crop production. Crit. Rev. Plant Sci. 2000, 19, 1-30. [CrossRef]

63. Vyas, P.; Gulati, A. Organic acid production in vitro and plant growth promotion in maize under controlled environment by phosphate-solubilizing fluorescent Pseudomonas. BMC Microbiol. 2009, 9, 174. [CrossRef] [PubMed]

64. Chen, Y.P.; Rekha, P.D.; Arun, A.B.; Shen, F.T.; Lai, W.A.; Young, C.C. Phosphate solubilizing bacteria from subtropical soil and their tricalcium phosphate solubilizing abilities. Appl. Soil Ecol. 2006, 34, 33-41. [CrossRef]

65. Shen, J.; Yuan, L.; Zhang, J.; Li, H.; Bai, Z.; Chen, X.; Zhang, W.; Zhang, W. Phosphorus dynamics: From soil to plant. Plant Physiol. 2011, 156, 998-1005. [CrossRef] [PubMed]

66. Hayat, R.; Ali, S.; Amara, U.; Khalid, R.; Ahmed, I. Soil beneficial bacteria and their role in plant growth promotion: A review. Ann. Microbiol. 2010, 60, 579-598. [CrossRef]

67. Glick, B.R. Bacteria with ACC deaminase can promote plant growth and help to feed the world. Microbiol. Res. 2014, 169, 30-39. [CrossRef]

68. Lambrecht, M.; Okon, Y.; Vande Broek, A.; Vanderleyden, J. Indole-3-acetic acid: A reciprocal signaling molecule in bacteria-plant interactions. Trends Microbiol. 2000, 8, 298-300. [CrossRef]

69. Steenhoudt, O.; Vanderleyden, J. Azospirillum, a free-living nitrogen-fixing bacterium closely associated with grasses: Genetic, biochemical and ecological aspects. FEMS Microbiol. Rev. 2000, 24, 487-506. [CrossRef]

70. Ferreira, M.; Silva, H.; Cunh, A. Siderophore-producing rhizobacteria as a promising tool for empowering plants to cope with iron limitation in saline soils: A review. Pedosphere 2019, 29, 409-420. [CrossRef]

71. Rudrappa, T.; Biedrzycki, M.L.; Kunjeti, S.G.; Donofrio, N.M.; Czymmek, K.J.; Paré, P.W.; Bais, H.P. The rhizobacterial elicitor acetoin induces systemic resistance in Arabidopsis thaliana. Comm. Integr. Biol. 2010, 3, 130-138. [CrossRef]

72. Sheng, X.F.; Xia, J.J.; Jiang, C.Y.; He, L.Y.; Qian, M. Characterization of heavy metal resistant endophytic bacteria from rape (Brassica napus) roots and their potential in promoting the growth and lead accumulation of rape. Environ. Pollut. 2008, 156, 1164-1170. [CrossRef]

73. Rajkumar, M.; Ae, N.; Prasad, M.N.V.; Freitas, H. Potential of siderophore-producing bacteria for improving heavy metal phytoextraction. Trends Biotechnol. 2009, 28, 142-149. [CrossRef] [PubMed]

74. Yuan, H.; Xu, Y.; Chen, Y.; Zhan, Y.; Wei, X.; Li, L.; Wang, D.; He, P.; Li, S.; Chen, S. Metabolomics analysis reveals global acetoin stress response of Bacillus licheniformis. Metabolomics 2019, 15, 25. [CrossRef] [PubMed] 
75. Croes, S.; Weyens, N.; Janssen, J.; Vercampt, H.; Colpaert, J.V.; Carleer, R.; Vangronsveld, J. Bacterial communities associated with Brassica napus L. grown on trace element-contaminated and non-contaminated fields: A genotypic and phenotypic comparison. Microb. Biotechnol. 2013, 6, 371-384. [CrossRef] [PubMed]

76. Truyens, S.; Weyens, N.; Cuypers, A.; Vangronsveld, J. Changes in the population of seed bacteria of transgenerationally Cd- exposed Arabidopsis thaliana. Plant Biol. 2013, 15, 971-981. [CrossRef]

77. Carlos, M.-H.J.; Janette, A.-M.; Melani, M.-S. Assessing the effects of heavy metals in ACC deaminase and IAA production on plant growth-promoting bacteria. Microbiol. Res. 2016, 188, 53-61. [CrossRef]

78. Akinrinlola, R.J.; Yuen, G.Y.; Drijber, R.A.; Adesemoye, A.O. Evaluation of Bacillus strains for plant growth promotion and predictability of efficacy by in vitro physiological traits. Int. J. Microbiol. 2018, 2018, 5686874. [CrossRef]

79. Ortíz-Castro, R.; Valencia-Cantero, E.; López-Bucio, J. Plant growth promotion by Bacillus megaterium involves cytokinin signaling. Plant Signaling Behavior 2008, 3, 263-265. [CrossRef]

80. Pueyo, M.T.; Bloch, C.J.; Carmona, R.A.M.; Masico, P. Lipopeptides produced by a soil Bacillus megaterium strain. Microb. Ecol. 2009, 57, 367-378. [CrossRef]

81. Govindasamy, V.; Senthilkumar, M.; Magheshwaran, V.; Kumar, U.; Bose, P.; Sharma, V.; Annapurna, K. Bacillus and Paenibacillus spp.: Potential PGPR for Sustainable Agriculture. In Plant Growth and Health Promoting Bacteria; Maheshwari, D.K., Ed.; Microbiology Monographs 18; Springer: Berlin/Heidelberg, Germany, 2010; pp. 333-364.

82. Cochrane, S.A.; Vederas, J.C. Lipopeptides from Bacillus and Paenibacillus spp.: A gold mine of antibiotic candidates. Med. Res. Rev. 2016, 36, 4-31. [CrossRef]

83. Elhalag, K.M.; Messiha, N.A.S.; Emara, H.M.; Abdallah, S.A. Evaluation of antibacterial activity of Stenotrophomonas maltophilia against Ralstonia solanacearum under different application conditions. J. Appl. Microbiol. 2016, 12, 1629-1645. [CrossRef]

84. Singh, R.P.; Jha, P.N. The PGPR Stenotrophomonas maltophilia SBP-9 augments resistance against biotic and abiotic stress in wheat plants. Front. Microbiol. 2017, 8, 1945. [CrossRef] [PubMed]

(C) 2020 by the authors. Licensee MDPI, Basel, Switzerland. This article is an open access article distributed under the terms and conditions of the Creative Commons Attribution (CC BY) license (http://creativecommons.org/licenses/by/4.0/). 